\title{
Financial Geographies and Emerging Markets in Europe
}

\author{
Bas Karreman
}

Forthcoming in the Journal of Economic and Social Geography

\begin{tabular}{|l|l|}
\hline \multicolumn{2}{|l|}{ ERIM REPORT SERIES RESEARCH IN MANAGEMENT } \\
\hline ERIM Report Series reference number & ERS-2008-054-ORG \\
\hline Publication & August 2008 \\
\hline Number of pages & 12 \\
\hline Persistent paper URL & http://hdl.handle.net/1765/13222 \\
\hline Email address corresponding author & karreman@few.eur.nl \\
\hline Address & Erasmus Research Institute of Management (ERIM) \\
& RSM Erasmus University / Erasmus School of Economics \\
& Erasmus Universiteit Rotterdam \\
& P.O.Box 1738 \\
& 3000 DR Rotterdam, The Netherlands \\
& Phone: + 31 10 408 1182 \\
& Fax: $\quad+31104089640$ \\
& Email: info@erim.eur.nl \\
& Internet: www.erim.eur.nl \\
\hline
\end{tabular}

Bibliographic data and classifications of all the ERIM reports are also available on the ERIM website: www.erim.eur.nl 


\section{ERASMUS RESEARCH INSTITUTE OF MANAGEMENT}

\section{REPORT SERIES \\ RESEARCH IN MANAGEMENT}

\begin{tabular}{|l|l|}
\hline ABSTRACT AND KEYWORDS \\
\hline Abstract & $\begin{array}{l}\text { This study examines the contemporary financial geographies in Central and Eastern Europe and } \\
\text { argues how these may affect the established European finacial centre network in the future. As } \\
\text { the development of the financial sector in Europe's emerging markets is largely dependent on } \\
\text { foreign investments, explicit attention is directed to determine which emerging centres exhibit } \\
\text { sufficient power to attract multinational financial service firms. In addition, it is empirically } \\
\text { assessed form which locations these investments are controlled. The results show a distinct } \\
\text { spatial order of financial centres organized around three main city clusters: a 'south-east' cluster } \\
\text { controlled by Athens, a 'central-east' cluster around Vienna and a 'Baltics' cluster directed from } \\
\text { Copenhagen and Stockholm. Based on the results it is argued that these centres of control, with } \\
\text { Vienna in particular, may enhance their competitiveness as a financial centre due to their } \\
\text { strategic position in the growing markets of Central and Eastern Europe. }\end{array}$ \\
\hline Free Keywords & $\begin{array}{l}\text { multinational banks, parent-subsidiary links, financial centres, city clusters, Central and Eastern } \\
\text { Europe }\end{array}$ \\
\hline Availability & $\begin{array}{l}\text { The ERIM Report Series is distributed through the following platforms: } \\
\text { Academic Repository at Erasmus University (DEAR), DEAR ERIM Series Portal } \\
\text { Social Science Research Network (SSRN), SSRN ERIM Series Webpage } \\
\text { Research Papers in Economics (REPEC), REPEC ERIM Series Webpage }\end{array}$ \\
\hline Classifications & $\begin{array}{l}\text { The electronic versions of the papers in the ERIM report Series contain bibliographic metadata } \\
\text { by the following classification systems: } \\
\text { Library of Congress Classification, (LCC) LCC Webpage } \\
\text { Journal of Economic Literature, (JEL), JEL Webpage } \\
\text { ACM Computing Classification System CCS Webpage } \\
\text { Inspec Classification scheme (ICS), ICS Webpage }\end{array}$ \\
\hline
\end{tabular}


FINANCIAL GEOGRAPHIES AND EMERGING MARKETS IN EUROPE

\title{
BAS KARREMAN*
}

*Department of Applied Economics, Erasmus University Rotterdam, P.O. Box 1738, 3000 DR Rotterdam, The Netherlands.E-mail: karreman@few.eur.nl

\begin{abstract}
This study examines the contemporary financial geographies in Central and Eastern Europe and argues how these may affect the established European financial centre network in the future. As the development of the financial sector in Europe's emerging markets is largely dependent on foreign investments, explicit attention is directed to determine which emerging centres exhibit sufficient power to attract multinational financial service firms. In addition, it is empirically assessed from which locations these investments are controlled. The results show a distinct spatial order of financial centres organised around three main city clusters: a 'south-east' cluster controlled by Athens, a 'central-east' cluster around Vienna and a 'Baltics' cluster directed from Copenhagen and Stockholm. Based on the results it is argued that these centres of control, with Vienna in particular, may enhance their competitiveness as a financial centre due to their strategic position in the growing markets of Central and Eastern Europe.
\end{abstract}

Key words: multinational banks, parent-subsidiary links, financial centres, city clusters, Central and Eastern Europe.

Version: August 2008. 


\section{INTRODUCTION}

"The heat goes on..." The subtitle of the latest Central and Eastern Europe (henceforth CEE) banking sector report of Raiffeisen Research (2007) emphasizes the outstanding prospects for further financial development of the region, and the still ample opportunities for foreign banks to tap into the region's market potential. ${ }^{1}$ As such, the rise of CEE countries into the global marketplace, could not have taken place without rigorous transformations in the financial sector. Key drivers of this transformation process have been the gradual privatisation of stateowned banks and the opening up of the banking sector to foreign investment (Naaborg et al. 2004). As a consequence, most of these countries enabled themselves to attract large inflows of foreign investments into the banking sector. As of today, over half the number of banks in CEE is foreign-owned and, with a majority of total bank assets, foreign banks have become a predominant factor in the development of the banking system in European transition economies.

As a result of the continuing large inflows of foreign investments, new localities of financial importance are establishing throughout Europe. Whereas new financial centres emerge in the CEE region, already existing ones in Western Europe are reconsidering their market focus. Especially those West European cities within close geographical proximity of the CEE (like for example Vienna, Athens and Stockholm) encounter new challenges to improve the competitive position of their financial centres. Unfortunately, the ongoing interests in the reconfiguration of European financial geographies is still directed to the core financial centres of London and Frankfurt (Beaverstock et al. 2005; Faulconbridge 2004; Clark, 2002; Grote et al. 2002) or towards a major centre like Amsterdam (Engelen 2007; Faulconbridge et al. 2007). Only few studies have been conducted which take a closer look at the spatial implications of the financial sector developments in CEE. A recent contribution is Wójcik (2007), who provides a detailed case study on the geographical nature of the Warsaw stock exchange activities. Based on the (non-)existing literature, it appears necessary to introduce a new field of discussion for two simple reasons. First, while most of the developments still take place in the European periphery, the dynamics of the region and the (future) accession of these CEE countries into the EU also affect the activities performed in

\footnotetext{
${ }^{1}$ In this study CEE is consisting of Central Europe (CE), South Eastern Europe (SEE), the Baltics and the Commonwealth of Independent States (CIS). CE includes Poland, Hungary, Czech Republic, Slovakia and Slovenia. SEE includes Croatia, Romania, Bulgaria, Serbia, Bosnia-Herzegovina, Republic of Macedonia and Albania. The Baltics include Estonia, Latvia and Lithuania. And finally, CIS includes Russia, Ukraine, Republic of Moldova and Belarus.
} 
the core centres. Second, and probably more important, several of these peripheral financial centres have the potential to become of considerable importance in the nearby future.

The purpose of this study is to examine the contemporary financial geographies in CEE, and building on that, to determine what the impact of these geographies may be on the established financial centre network in Western Europe. To accomplish this, two questions are empirically assessed. First, which financial centres in CEE exhibit sufficient power to attract multinational financial service firms? And second, from where are these investments controlled? As the capital markets in CEE are relatively underdeveloped, firms in need of external funds are still highly dependent on bank credit. Therefore, this paper takes up a banking approach to financial centre development. Before discussing the empirical outcomes of this study, some literature is reviewed on the spatial implications of financial development in transition economies.

\section{THE SPATIAL IMPLICATIONS OF FINANCIAL DEVELOPMENT IN CEE}

Throughout the transition process towards a market based economy, the development of the banking sectors in the CEE countries was hampered by many difficulties inherited from the system of central planning. Main examples are large stocks of non-performing loans, low savings and investment levels, low productivity and geographically and sectorally concentrated loan portfolios (Blommestein \& Spencer 1994). In order to overcome these problems and to instil discipline in the market, most countries gradually restructured, recapitalised and privatised their state-owned commercial banks and opened up the domestic banking sector to foreign competition and investment (Naaborg et al. 2004). The results of this strategy were as expected. Due to their low level of competitiveness, the inefficient domestic banks faced the loss of market share and became interesting targets for take-over by foreign financial institutions. Consequently, this triggered a surge of foreign investments in the banking sector, causing a true investment and acquisition wave throughout most of CEE during the last decade.

Spatial diversity in CEE - Foreign investments in the banking sector are not evenly distributed among the various countries in the CEE. Depending on the degree of financial development in terms of financial regulation and the general business environment, national or sub-national spaces are maintained (Budd 1995). This indicates that the heterogeneity of the financial-economic conditions across space has serious implications for the investments 
decisions of foreign financial institutions. When considering national spaces, figure 1 shows that while in the CE, SEE and the Baltics foreign-owned firms are dominant in the banking sector (with the exception of Slovenia), foreign presence in the CIS countries is considerably lower. This difference between CIS and the other regions is primarily caused by differences in the level of financial development and the regulatory measures of the CIS state authorities to protect the domestic banking sector against international competition. Furthermore, the high degree of foreign ownership in the banking sector of the CEE countries implies a strong financial dependence on other countries outside CEE.

\section{[Figure 1 about here]}

How about sub-national spaces? Obviously foreign financial institutions try to choose the optimal location to set up their business within a particular country. However, as the most frequently used mode of entry of foreign banks in CEE is through an acquisition (Naaborg et al. 2004), these banks are constrained by the locational inertia of the existing office locations and network of the acquired bank (see Porteous 1999). As most of these domestic banks have a history as a state-owned bank (which was generally co-located with the state planning agency), their head-office locations are typically concentrated in the financial centre of each country's capital. In addition, foreign banks have the tendency to focus their activities mainly on large borrowers (Berger et al. 2001). In former centrally planned economies these large borrowers are, in most cases, real sector companies with a past of state ownership. Similar to the domestic banks, these companies are predominantly located in the capital city. For regions more remote from the financial centre, the high market share of foreign financial institutions in the domestic banking sector may lead to rather constrained credit availability (Dow, 1999). Therefore, sub-national spaces in CEE are determined by particular spatial-economic profiles still largely resulting from each country's history as a centrally planned economy.

Foreign investments - In an expanding European market, multinational financial institutions are positioning themselves to cope with the increasing pressures of international competition. A primary policy is to search for new strategic markets and to increase the geographical scope and market power of the firm (see Dermine 2006). The transition markets of CEE prove to provide interesting new opportunities, especially for those financial institutions within close geographical proximity of the region. Table 1 provides an overview of the investments of the largest foreign investors in the banking sectors of CEE. The ranking is dominated by banks 
from Western Europe, with USA based Citibank and Hungary's national champion OTP being the exceptions. There are two additional noteworthy details included in table 1. First, some of Europe's largest financial institutions are not extensively investing in the region. London based HSBC and Barclays for example, have only (very) limited stakes in CEE. The same holds true for Frankfurt's giant Deutsche Bank. Second, Austrian banks are well represented in the top 10. Besides Erste Bank and Raiffeisen, there is Bank Austria headquartered in Vienna which is, as a member of the Italian UniCredit Group, responsible for the activities throughout CEE.

\section{[Table 1 about here]}

The fact that mostly West European financial institutions are investing in CEE indicates a specific role of distance. As indicated by Grote et al. (2002), various dimensions of proximity, like cultural, organisational, institutional or geographical proximity, are among the main determinants of the financial sector's spatial organisation. These different dimensions of proximity are united by the fact that they reduce uncertainty (Boschma 2005) and, therefore, make it less hard and costly for financial firms to manage the risk profile of an investment project. For financial institutions located within close proximity of the CEE region it may therefore be more appealing to invest as compared to other multinational financial institutions.

\section{FINANCIAL CENTRE NETWORKS: METHODOLOGY AND DATA}

In order to examine the contemporary financial geographies in CEE and to explore the interregional attachments with West European financial centres empirically, this paper takes up a network approach. Building on the ideas of the world city literature (e.g. Beaverstock et al. 2000; Taylor 2001), financial centres are considered to be interlocked by the office networks of multinational financial institutions. Taking up the view that the financial centres are a result of the networks and relations they possess and the flows they produce (Faulconbridge 2004), it becomes easier to understand the role they play in the European system of financial centres. In this context, the power of a financial centre in CEE is determined by the number of different connections with its West European counterparts, whereby the connections represent the past investments of foreign financial institutions in the centre. In turn, financial institutions located in Western Europe are controlling their 
investments in CEE. The size of the number of investing banks from a particular financial centre is what constitutes the involvement of the centre in the CEE region. This indicates that the emerging centres in CEE are considered based on connectivity-through-subordination network (Taylor et al. 2002).

The data sample is retrieved from the Bankscope database (2007 edition) provided by Bureau van Dijk, which contains data for about 13.000 banks worldwide. Due to fact that most of the investments in CEE by foreign financial institutions are performed through a stepwise acquisition, it can become hard to distinguish whether an office is a true subsidiary or not based on the degree of ownership. Therefore, only those CEE offices in which a foreign investor has a direct or indirect ownership of $\geq 50$ percent are included. Furthermore, as the analysis is limited to the banking sector, the sample is restricted to foreign subsidiaries of multinational financial institutions classified in Bankscope as commercial banks, savings banks, cooperative banks and medium/long term credit banks. Finally, the parent bank has to be European with it's headquarter located outside CEE, with subsidiaries located in CEE.

\section{RESULTS: CITY CLUSTERS IN BANKING}

\section{[Figure 2 about here]}

Figure 2 provides an overview of the total degree of financial centre connectivity in Europe. The main findings are fourfold. First, banks headquartered in Vienna play a crucial role as foreign investors in CEE. These investments are predominantly from Austria based banks, but as indicated by the relatively large indegree of financial centre links, financial institutions headquartered in other financial centres in Western Europe use their subsidiary in Vienna as a gateway to CEE. Second, alongside Vienna, the financial centres which host the main investors in CEE are Paris, Athens and Frankfurt. Interestingly enough, there are only minor connections between London based banks and CEE. Third, besides Vienna, Athens, Amsterdam and Helsinki perform roles as gateways to CEE, which are largely due to (recent) merger and acquisition activity between Western European banks. For example, Crédit Agricole controls its market share in Albania, Bulgaria and Romania through the acquired Emporiki Bank of Greece headquartered in Athens, while Spanish Banco Santander acquired the CEE subsidiaries of ABN-AMRO which are still directed from Amsterdam at the time of writing. Fourth, the financial centres in CEE with the highest number of foreign investors in banking are, in respective order, Moscow, Warsaw and Budapest. These findings are not 
surprising as they largely correspond with the outcomes of the research by Taylor \& Hoyler (2000) on the spatial order of European cities in terms of corporate service complexes.

\section{[Figure 3 about here]}

While figure 2 makes clear which financial centres in CEE have sufficient power to attract foreign investments into the banking sector, figure 3 explicitly shows from where these investments are controlled. The parent-subsidiary network shows a distinct spatial configuration of financial centres organized around three main city clusters: a SEE-cluster controlled by Athens, a CE-cluster around Vienna and a Baltics-cluster directed from Copenhagen and Stockholm. In addition, Paris, Frankfurt, Brussels and Milan host a large number of investors, but these do not concentrate on a particular cluster of regions in CEE, though Paris has explicit linkages with Moscow and Kiev the main financial centres in CIS.

\section{CONCLUSIONS}

While the literature concerning the dynamics of European financial geographies is burgeoning, little attention has been directed to the rapid (financial) developments in CEE. In this paper it is shown that the financial sector developments in CEE are largely dependent on the investments made by financial institutions from Western Europe. This indicates that a further rise of CEE will most probably also affect the dynamics of the established European financial geographies, not only in the peripheral but, if growth continues, eventually also in the core financial centres. The outcomes of the empirical analysis show that the contemporary foreign involvement in the banking sectors of $\mathrm{CEE}$ is predominantly controlled from neighbouring countries. Stockholm, Vienna and Athens for example, host the headquarters of large investors in the Baltics, CE and SEE respectively. Although these financial centres are still considered to be peripheral, their strategic position in their respective adjacent region may enhance their competitiveness as a financial centre in the future. Especially the financial centre of Vienna, which performs a central role as financial service provider to CE, may profit considerably in terms of competitiveness when the heat keeps on going in CEE in the future. 


\section{REFERENCES}

BEAVERSTOCK, J.V., M. HOYLER, K. PAIN \& P.J. TAYLOR (2005), Demystifying the Euro in the European Financial Centre Relations: London and Frankfurt, 2000-2001. Journal of Contemporary European Studies 13, pp. 143-157.

BEAVERSTOCK, J.V., R.G. SMITH \& P.J. TAYLOR (2000), World City Network: A New Metageography? Annals of the Association of American Geographers 90, pp. 123-134.

BERGER, R.A., L.F. KLAPPER \& G.F. UDELL (2001), The Ability of Banks to Lend to Informational Opaque Small Businesses. Journal of Banking and Finance 25, pp. $2127-$ 2167.

BLOMMESTEIN, H.J. \& M.G. SPENCER (1994), The Role of Financial Institutions in the Transition to a Market Economy. In: G. CAPRIO, D. FOLKERTS-LANDAU \& T.D. LANE, eds., Building Sound Finance in Emerging Market Economies, pp. 139-189. Washington: IMF.

BOSCHMA, R.A. (2005), Proximity and Innovation: A Critical Assessment. Regional Studies 39 , pp.61-74.

BUDD, L. (1995), Globalisation, Territory and Strategic Alliances in Different Financial Centres. Urban Studies 32, pp. 345-360.

CLARK, G.L. (2002), London in the European Financial Services Industry: Locational Advantage and Product Complementarities. Journal of Economic Geography 2, pp. 433453.

DERMINE, J. (2006), European Banking Integration: Don't Put the Cart before the Horse. Financial Markets, Institutions and Instruments 15, pp.57-106.

DOW, S.C (1999), The Stages of Banking Development and the Spatial Evolution of Financial Systems. In: MARTIN, R. ed., Money and the Space Economy, pp. 31-48. Chichester: Wiley.

ENGELEN, E. (2007), 'Amsterdamned'? The Uncertain Future of a Financial Centre. Environment and Planning A 39, pp. 1306-1324.

FAULCONBRIDGE, J.R. (2004), London and Frankfurt in Europe's Evolving Financial Centre Network. Area 36, pp. 235-244.

FAULCONBRDIGE, J.R., E. ENGELEN, M. HOYLER \& J. BEAVERSTOCK (2007), Analysing the Changing Landscape of European Financial Centres: The Role of Financial Products and the Case of Amsterdam. Growth and Change 38, pp. 279-303. 
GROTE, M.H., V. LO \& S. HARRSCHAR-EHRNBORG (2002), A Value-Chain Approach to Financial Centres - The Case of Frankfurt. Tijdschrift voor Economische en Sociale Geografie 93, pp. 412-423.

NAABORG, I., B. SCHOLTENS, J. DE HAAN, H. BOL \& R. DE HAAS (2004), How Important are Foreign Banks in the Financial Development of European Transition Countries? Journal of Emerging Market Finance 3, pp. 99-123.

PORTEOUS, D.J. (1999), The Development of Financial Centres: Location, Information Externalities and Path Dependence. In: MARTIN, R. ed., Money and the Space Economy, pp. 95-114. Chichester: Wiley.

RAIFFEISEN RESEARCH (2007), Raiffeisen Research CEE Banking Sector Report 2007. Vienna: RZB Group.

TAYLOR, P.J. (2001), Specification of the World City Network. Geographical Analysis 33, pp.181-194.

TAYLOR, P.J. \& M. HOYLER (2000), The Spatial Order of European Cities under Conditions of Contemporary Globalisation. Tijdschrift voor Economische en Sociale Geografie 91, pp. 176-189.

TAYLOR, P.J., D.R.F. WALKER, G. CATALANO \& M. HOYLER (2002), Diversity and Power in the World City Network. Cities 19, pp.231-241.

WÓJCIK, D. (2007), Geography and Future of Stock Exchanges: Between Real and Virtual Space. Growth and Change 38, pp. 200-223. 


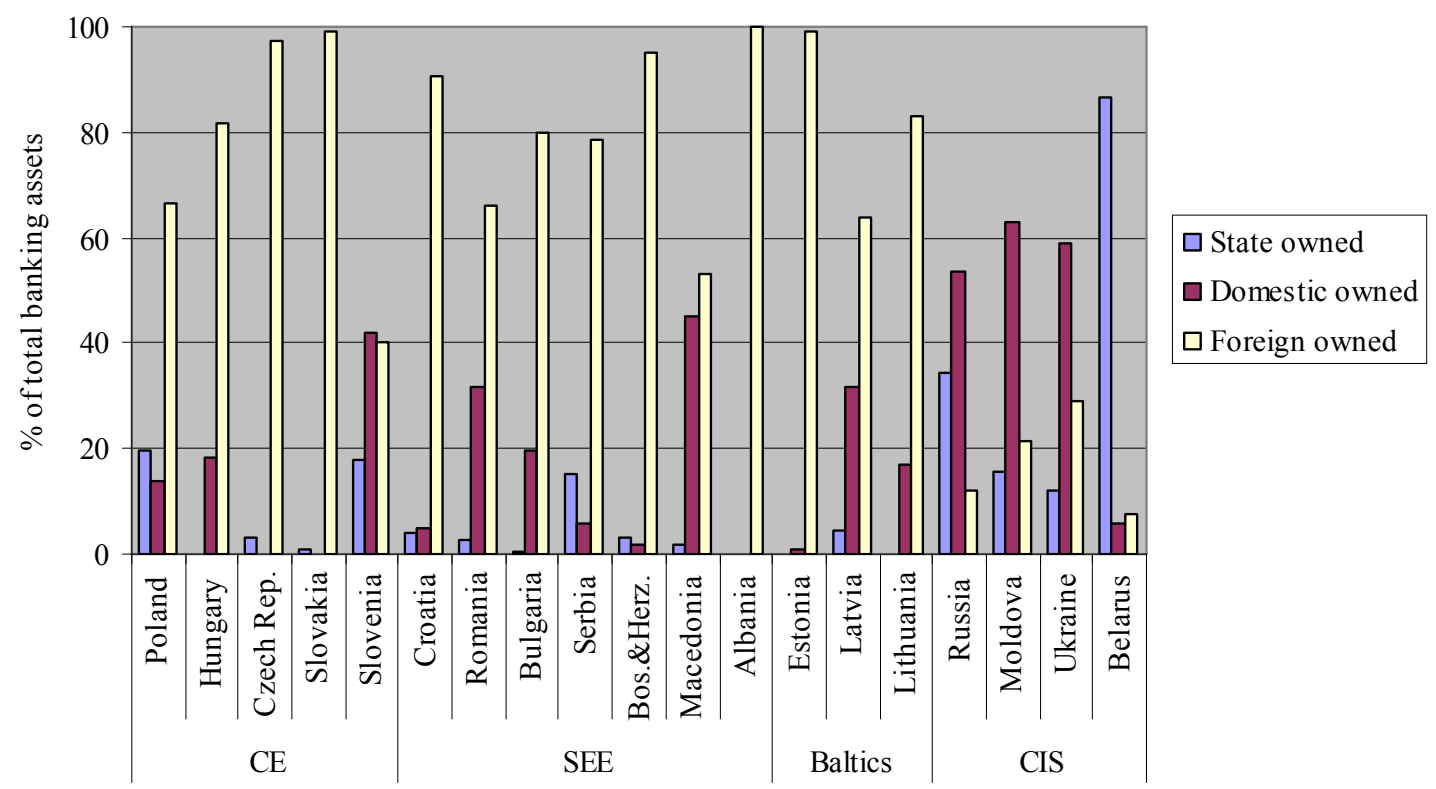

Source: Raiffeisen Research (2007) and local central banks.

Note: Data as of year-end 2006.

Figure 1. Market share of majority foreign-owned banks in CEE 2007.

Table 1. Top-10 largest international banks and their market share in CEE 2007.

\begin{tabular}{llllcc}
\hline Ranking & Bank & Country & HQ City & $\begin{array}{l}\text { Consolidated } \\
\text { total assets } \\
\text { (EUR billion) }\end{array}$ & $\begin{array}{l}\text { Total market } \\
\text { share (\%) }\end{array}$ \\
\hline 1 & UniCredit & Italy & Roma & 91.0 & 7.6 \\
2 & Erste Bank & Austria & Vienna & 59.3 & 4.9 \\
3 & Raiffeisen & Austria & Vienna & 55.9 & 4.6 \\
4 & KBC & Belgium & Brussels & 43.3 & 3.6 \\
5 & Société Genérale & France & Paris & 40.0 & 3.3 \\
6 & OTP & Hungary & Budapest & 31.5 & 2.6 \\
7 & Intesa Sanpaolo & Italy & Milan & 27.9 & 2.3 \\
8 & ING & Netherlands & Amsterdam & 21.1 & 1.8 \\
9 & Citibank & USA & New York & 20.6 & 1.7 \\
10 & Swedbank & Sweden & Stockholm & 20.2 & 1.7 \\
\hline
\end{tabular}

Source: Raiffeisen Research (2007) and local central banks.

Note: Data as of year-end 2006, representing ownership structure as of September 2007. 


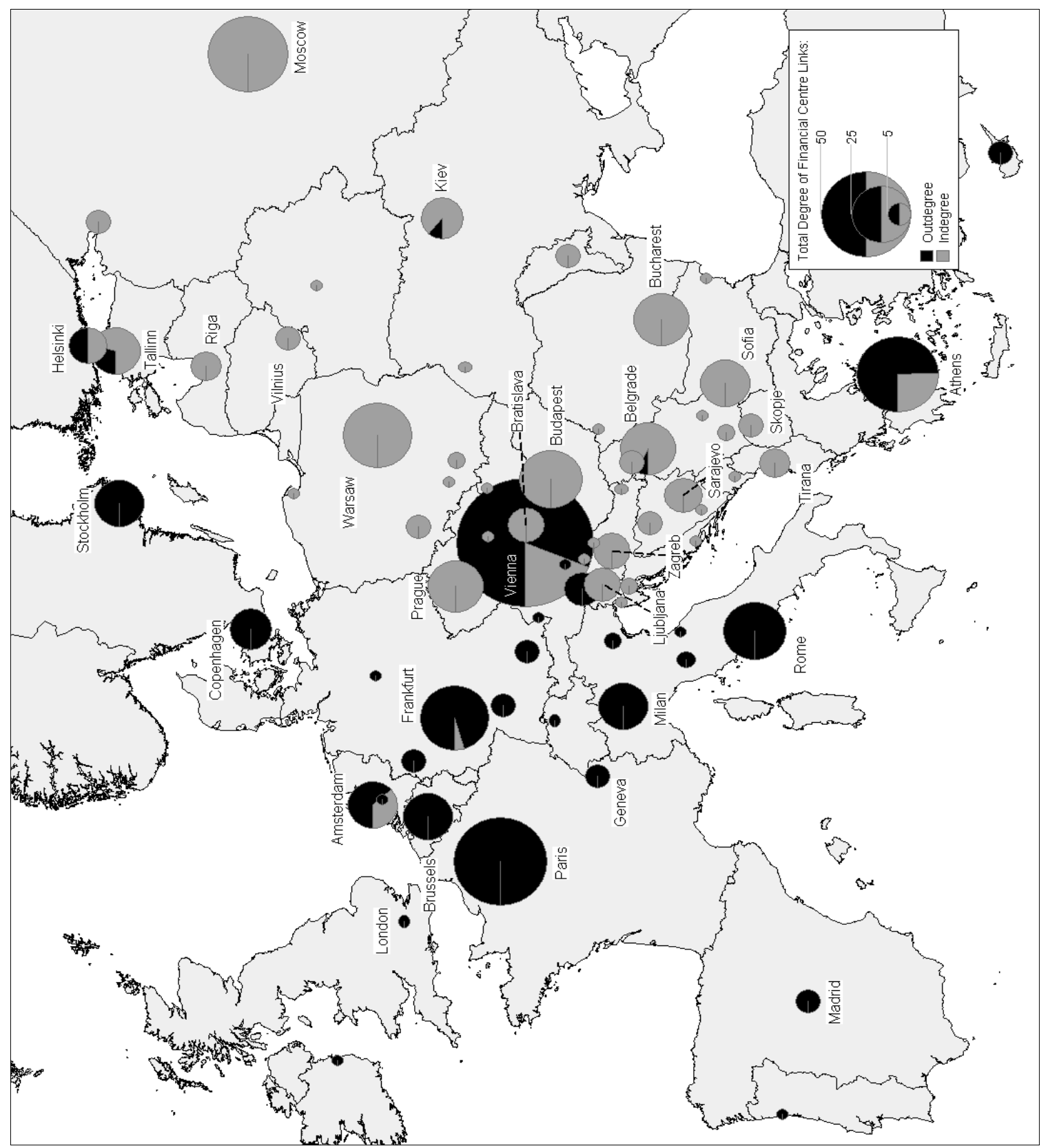

Figure 2. Degree of financial centre connectivity in Western Europe and CEE 2007. 


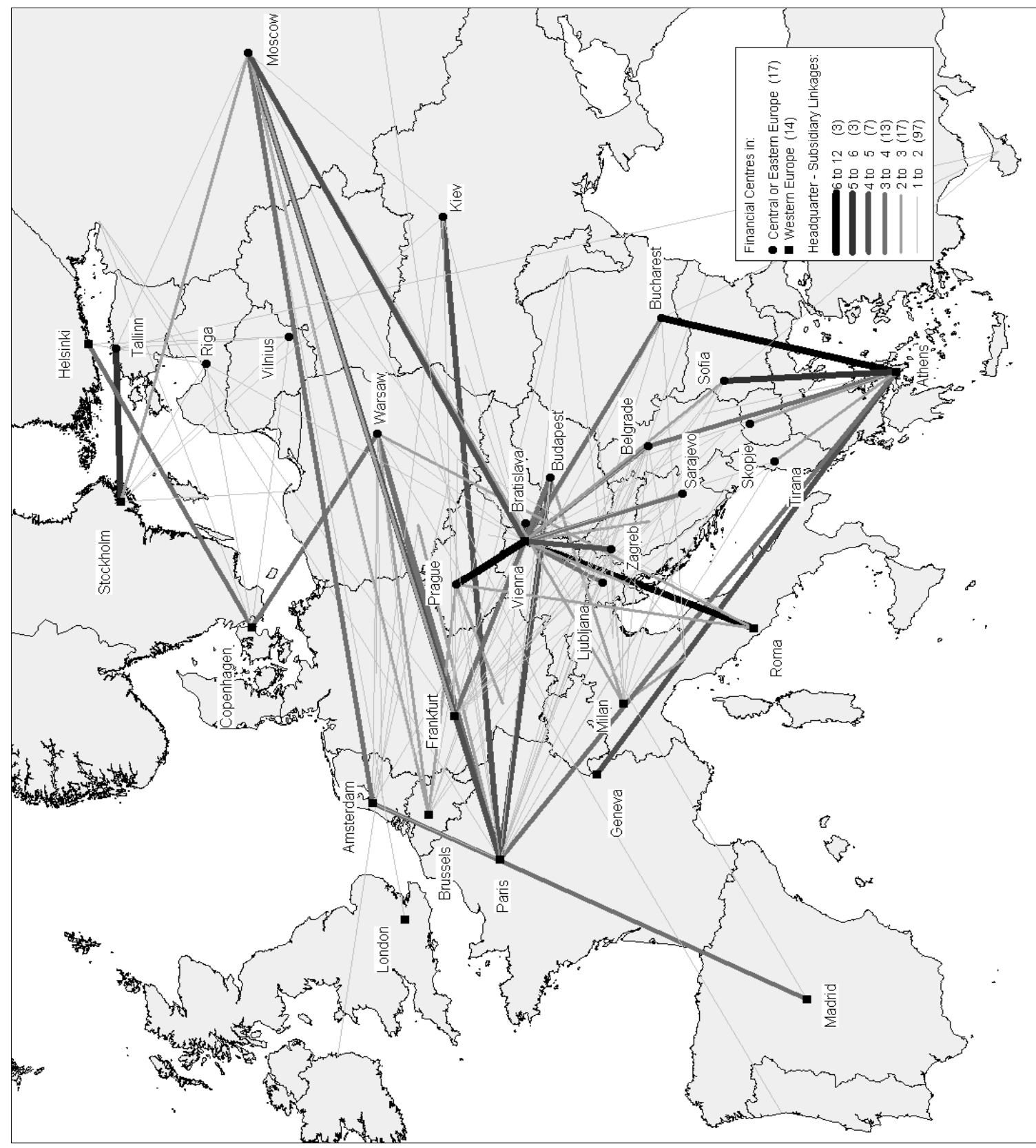

Figure 3. Parent-Subsidiary links of West European banks to their subsidiaries in CEE 2007. 


\section{Publications in the ERIM Report Series Research* in Management}

\section{ERIM Research Program: "Organizing for Performance"}

\section{8}

Explaining Preferences and Actual Involvement in Self-Employment: New Insights into the Role of Gender Ingrid Verheul, Roy Thurik and Isabel Grilo ERS-2008-003-ORG

http://hdl.handle.net/1765/10979

Public Finance in China since the Late Qing Dynasty

Barbara Krug

ERS-2008-005-ORG

http://hdl.handle.net/1765/11287

Overoptimism among Founders: The Role of Information and Motivation

Ingrid Verheul and Martin Carree

ERS-2008-008-ORG

http://hdl.handle.net/1765/11557

Do Foreign Greenfields Outperform Foreign Acquisitions or Vice Versa? An Institutional Perspective

Arjen H.L. Slangen and Jean-François Hennart

ERS-2008-009-ORG

http://hdl.handle.net/1765/11558

Unemployment Benefits Crowd Out Nascent Entrepreneurial Activity

Philipp Koellinger and Maria Minniti

ERS-2008-012-ORG

http://hdl.handle.net/1765/11808

Acceleration of Technology Adoption within Firms: Empirical Evidence from the Diffusion of E-business Technologies Philipp Koellinger and Christian Schade

ERS-2008-013-ORG

http://hdl.handle.net/1765/11809

Belbin Revisited: The Construct Validity of the Interplace II Team Role Instrument

Dirk van Dierendonck and Rob Groen

ERS-2008-017-ORG

http://hdl.handle.net/1765/12123

China's Institutional Architecture: A New Institutional Economics and Organization Theory Perspective on the Links between Local Governance and Local Enterprises

Barbara Krug and Hans Hendrischke

ERS-2008-018-ORG

http://hdl.handle.net/1765/12191

Ethics Programs and Ethical Cultures: A Next Step in Unraveling their Multi-Faceted Relationship

Muel Kaptein

ERS-2008-020-ORG

http://hdl.handle.net/1765/12192

Entrepreneurship Education and Training in a Small Business Context: Insights from the Competence-based Approach Thomas Lans, Wim Hulsink, Herman Baert and Martin Mulder

ERS-2008-028-ORG

http://hdl.handle.net/1765/12466 
The Relationship between Technology, Innovation, and Firm Performance: Empirical Evidence on E-Business in Europe Philipp Koellinger

ERS-2008-031-ORG

http://hdl.handle.net/1765/12469

The Relationship between Ethical Culture and Unethical Behavior in Work Groups: Testing the Corporate Ethical Virtues Model

Muel Kaptein

ERS-2008-037-ORG

http://hdl.handle.net/1765/12783

Influence Costs in Agribusiness Cooperatives: Evidence from Case Studies

Constantine lliopoulos and George Hendrikse

ERS-2008-040-ORG

http://hdl.handle.net/1765/12872

The Locus of Innovation in Small and Medium-sized Firms: The Importance of Social Capital and Networking in Innovative Entrepreneurship

Willem Hulsink, Tom Elfring and Wouter Stam

ERS-2008-041-ORG

http://hdl.handle.net/1765/12873

Stimulating Strategically Aligned Behaviour among Employees

Cees B. M. van Riel, Guido Berens and Majorie Dijkstra

ERS-2008-045-ORG

http://hdl.handle.net/1765/12903

Creating Strategic Aligned Behavior among Employees at Philips

Cees B.M. van Riel and Guido Berens

ERS-2008-046-ORG

http://hdl.handle.net/1765/13218

Why Identify? Self-Enhancement and Self-Consistency Motives in Organizational Identification

Mirdita N. Elstak, Cees B.M. van Riel and Michael G. Pratt

ERS-2008-047-ORG

http://hdl.handle.net/1765/13219

Science and Technology-based Regional Entrepreneurship in the Netherlands: Building Support Structures for Business

Creation and Growth Entrepreneurship

Willem Hulsink, Kashifa Suddle and Jolanda Hessels

ERS-2008-048-ORG

http://hdl.handle.net/1765/13220

I Can't Get No Satisfaction - Necessity Entrepreneurship and Procedural Utility

Joern Block and Philipp Koellinger

ERS-2008-051-ORG

http://hdl.handle.net/1765/13221

Financial Geographies and Emerging Markets in Europe

Bas Karreman

ERS-2008-054-ORG

http://hdl.handle.net/1765/13222 
* A complete overview of the ERIM Report Series Research in Management: https://ep.eur.nl/handle/1765/1

ERIM Research Programs:

LIS Business Processes, Logistics and Information Systems ORG Organizing for Performance

MKT Marketing

F\&A Finance and Accounting

STR Strategy and Entrepreneurship 